\title{
SEPARATION OF FUNCTIONS AND THE NATIONAL LABOR RELA. TIONS BOARD
}

\begin{abstract}
Harold W. DaVEY*
HE administrative process has experienced rough going recently. Various quasi-erudite and legalistic groups have felt impelled to

1 inquire into the mysterious workings of this relatively novel development in American government. Some attempts have been merely fishing expeditions, ${ }^{x}$ others serious efforts to remedy what have been felt to be alarming defects in the system of "government by men."”

One principal feature of the administrative process has drawn general fire, namely, the combination of administrative, prosecutory and judicial functions under one roof in the federal independent tribunals. ${ }^{3}$ This is attacked as in violation of Coke's time-worn dictum that no man should be judge in his own cause. The latter concept still possesses sufficient vitality to evoke consternation from those who fear for the independence of our democratic institutions and the "rights of man." Such fears remain de-

* Instructor in Social Sciences, Armour Institute of Technology.

I For example, the present Congressional committee investigating the NLRB and headed by Representative Smith, whose legislative record has shown him to be definitely unsympathetic to labor. To date, no official report has been received from this body. See also Senator Burke's unsuccessful effort to instigate an investigation of the board in I938. S. Hearing entitled "Investigation of the National Labor Relations Board," 75th Cong. $3^{d}$ Sess. (1938). In general, see Jaffe, Invective and Investigation in Administrative Law, 52 Harv. L. Rev. I20 (I939).

2 See particularly, Cushman, The Problem of the Independent Regulatory Commissions, in Report with Special Studies, President's Committee on Administrative Management (r937), and the 1938 and 1939 reports of the American Bar Association's Committee on Administrative Law. For excellent general analysis see Stason, Administrative Tribunals-Organization and Reorganization, 36 Mich. L. Rev. 533 (1938), and Aitchison, Reforming the Administrative Process, 7 Geo. Wash. L. Rev. 703 (1939).

${ }^{3}$ See Inland Steel Co. v. NLRB, C.C.H. Lab. Law Serv. If I8510 (C.C.A. 7th I940), where the court sent the case back for a new hearing because of the trial examiner's alleged unfair and prejudicial conduct of the hearing. The court remarked in strong language about the "danger of imposing upon a single agency the multiple duties of prosecutor, judge, jury and executioner." It might be added that the last word is inaccurate. No board decision can be enforced except by order of the circuit courts.

Dean Pound, in his report to the American Bar Association, is particularly bitter about this combination of functions in one agency. See his 1939 report, passim. Contra: Landis, The Administrative Process (I938).
\end{abstract}


spite the fact that such a combination of functions has been held by our federal courts not to constitute a violation of any essential element of due process of law guaranteed by the Constitution.

The National Labor Relations Board, one of the newest and most powerful of the independent tribunals, has been constantly criticized on this point. Employers, disaffected labor groups and politicians of high and low degree have assailed the NLRB as a drumhead court martial, a Spanish inquisitory tribunal, and a "modern Judge Fury," to borrow one of Arthur Krock's favorite epithets. ${ }^{4}$ The stream of criticism has been of such imposing proportions as to warrant legitimate concern if even a portion of the charges against the board in this respect have validity.

There have appeared in legal periodicals several competent articles giving NLRB administrative procedure a clean bill, ${ }^{5}$ but these painstaking efforts have been all but overwhelmed by the veritable flood of adverse propaganda appearing in popular journals and in the newspapers. ${ }^{6}$ The establishment of the labor board illustrates the recognition of a new sense of legal responsibility on the part of the "relatively rich" to the "relatively poor." The NLRB bears such a fundamental relation to the well-being

${ }_{4}$ Attacks have been constant from all sources. See speeches by Senators Burke, Nye, Vandenburg (to mention but a few), or by William Green, Joseph Padway, or by leaders of the National Association of Manufacturers and of the United States Chamber of Commerce. The AFL at the past session of Congress proposed numerous procedural amendments to the act, one of which was to separate the judicial and administrative functions of the NLRB. This and other amendments were shelved, pending a report of an investigatory committee. See note I supra. Anti-union forces have been more successful in the states and have succeeded in securing passage of restrictive labor legislation in Oregon, Pennsylvania, Wisconsin, Michigan, and Minnesota. The recent Pennsylvania and Wisconsin laws are emasculations of original copies of the National Labor Relations Act.

5 See Wolf, Administrative Procedure before the National Labor Relations Board, 5 Univ. Chi. L. Rev. $35^{8}$ (1938); Gellhorn and Linfeld, Politics and Labor Relations: A Study of the Administrative Procedure of the NLRB, 39 Col. L. Rev. 339 (I939); Fahy, Procedure under the National Labor Relations Act, NLRB Rel. R-1337 (November I938); Madden, Administrative Procedure of the National Labor Relations Board, 45 W. Va. L. Q. 93 (1939); Fahy, Preparation and Trial of Cases before the NLRB, 25 A.B.A.J. 695 (1939); Janofsky, Procedure under the National Labor Relations Act, $\mathrm{r}_{3}$ L.A.B.A. Bull. 236 (I938). An excellent study, not yet in print, is that of Harry Merican, Administrative Procedure of the National Labor Relations Board.

${ }^{6}$ See editorials on the NLRB in the New York Times, the Chicago Tribune, Chicago Daily News, New York Herald Tribune, etc.; Bridges, The Inquisition Comes to America, I5 Liberty No. 20, at I6 (May I4, I938). The references on earlier anti-NLRB articles are collected in Smith, The Drive against the National Labor Relations Board, NLRB Rel. R-904 (May I938). Typical of recent diatribes against the board is Garrett, One to Make a Bargain, 212 Saturday Evening Post No. I3, at I4 (September I939). See also, the G- D- Labor Board, 8 Fortune No. 4, at 32 (October 1938).

7 Sharp and Gregory, Social Change and Labor Law 23 (1939). 
of the American industrial machine that it is clearly of the utmost importance that insofar as possible its administrative tactics be above reproach.

This article will explore problems in combination of diverse functions within the NLRB and conclude as to whether such combination has resulted in any unfairness to the parties subject to the board's jurisdiction. The writer wishes particularly to stress informal aspects of board procedure that have received but sparing attention in previous articles. ${ }^{8}$

In general, the administrative procedure of the NLRB follows the familiar independent commission pattern. In drafting the Wagner Act, liberal use was made of the content and language of the Federal Trade Commission statute.' Briefly, the National Labor Relations Act establishes an independent tribunal of three members with power to prevent commission of certain specified unfair labor practices, ${ }^{\text {,o }}$ and to designate authorized representatives of employees for purposes of collective bargaining. ${ }^{\mathrm{xx}}$ In its administrative machinery, the board employs a combination of centralization as to policy determination with an effective decentralization in administration. All investigation and informal settlement of cases are handled by the personnel of twenty-two regional offices throughout the country. The overwhelming preponderance of all cases coming to the board are closed without resort to formal procedure, either by dismissal, by withdrawal or by the conclusion of an informal settlement in compliance with the act. ${ }^{12}$ In only five percent of all cases does the dispute require a formal decision by the board. ${ }^{x^{3}}$ In themselves, these figures constitute a remarkable tribute to the administrative efficiency of the board and refute conclusively the frequent charge that NLRB proceedings have the sole purpose of "getting" the hapless employer.

Quite the contrary, only where no agreement is possible will the board proceed with a formal prosecution against the employer. "Instead of patrolling the area of regulation in pursuit of offenders, emphasis is being placed on evoking cooperative attitudes." ${ }^{24}$ The board properly recognizes

${ }^{8}$ The most thorough analysis of the board's procedure is that of Professors Gellhorn and Linfield. See note 5 supra. They specifically exclude, however, the subject of the present article.

9 Compare Section ro of the Wagner Act with Section 5 of the Trade Commission Act. In many paragraphs the wording is identical, and intentionally so. See Federal Trade Commission, Rules, Policy and Acts ( 1938 ).

Io See $\S 8,49$ Stat. 449, 452 (I935), 29 U.S.C.A. $§ 5_{5}^{8}$ (Supp. 1938). $\quad$ xx Ibid., $\S 9$.

12 During the last three years, board figures show that approximately ninety-four percent of all cases coming to the NLRB are disposed of without recourse to a formal decision.

${ }_{23}$ The percentage has alternated between five and six percent. For exact figures see the board's annual reports.

${ }_{4}$ Marx, Bureaucracy and Consultation, I Rev. of Politics 84, 89 (1939). 
that a formal cease and desist order is not the most effective medium for securing permanently satisfactory compliance with the terms and intent of the act. Its procedural policies evidence a full realization that the ultimate success of administrative control of labor relations depends on securing compliance through informal channels.

Where formal procedure is required, a public hearing ${ }^{15}$ is held before a trial examiner followed by a report to the board from the examiner. ${ }^{16}$ Oral argument and filing of briefs are available to the parties prior to the board's decision. No NLRB order is self-enforcing, and appeal by any party from a decision lies to the federal circuit courts. An order from the latter is necessary to compulsory enforcement. ${ }^{17}$

With this outline of the board's general procedure in mind, it is now possible to proceed to the main discussion relating to combination of administrative, prosecutory and judicial functions within one agency. In judging the NLRB's policies, it should be recalled that criticisms of the board in this respect apply also to the other independent commissions. Most of these agencies combine allegedly conflicting functions in varying degrees. But the fact that there is this fusion of prosecution and adjudication in a single tribunal does not imply the absence of all extrinsic checks. As Dean Landis points out, ${ }^{18}$ it simply implies absence of the traditional check. Such a combination of functions does not offend constitutional requirements of due process. Consequently, the standard here for judging the NLRB will be whether the board has achieved an effective separation of functions insuring preservation of essential elements of fair play as well as the basic minimum of due process of law.

One more qualification requires mention. The NLRB handles two broad classes of disputes, (I) those involving charges of unfair labor practices, termed in staff language " $\mathrm{C}$ " cases, and (2) representation disputes. In the latter, the board proceeds against no one but rather provides a medium for investigation to determine who is the legally authorized representative

is All board hearings have been and are open to the general public, except where the testimony may prove personally embarrassing to the witness. In such circumstances, the court is temporarily cleared.

${ }^{16}$ Such a report is in writing and is served on all parties. The latter have a fixed and ample period of time in which to file exceptions.

${ }^{17}$ This fact is often ignored by those who prattle of "administrative absolutism." There are no criminal penalties attached to the Wagner Act, except for wilful obstruction of the NLRB's performance of its statutory function. It might also be noted that the board cannot initiate prosecutions. It acts only upon receipt of formally filed charges and cannot conduct headhunting forays on its own motion.

${ }^{28}$ Landis, op. cit. supra note 3 , at 98 . See also the chapter on Procedure in Brooks, Unions of Their Own Choosing (r939). 
of employees for collective bargaining purposes. ${ }^{19}$ In a complaint case, on the other hand, proceedings are adversary from the moment a formal board complaint issues against the employer. It is in the latter type of case, therefore, that the problem of separating conflicting functions becomes acute. It is here that the board is truly both prosecutor and judge. It is here that it becomes important to learn whether the NLRB's administrative policies reflect a judicial attitude and a temperate consideration for the rights of the parties at interest.

Centralized control over the issuance of complaints affords the first opportunity in the NLRB's administrative process for a possible undesirable mixing of judicial and administrative functions. If board members themselves were to decide in each case whether a complaint should issue on the basis of specific evidence at hand and then proceeded later to decide the same cases, there might be legitimate criticism that the same individuals were combining prosecutory and judicial activities. Administratively, such a condition seldom arises. Regional directors' requests for authority to issue complaints are normally handled by the executive secretary or his legal assistants. Occasionally, the board may personally decide whether a complaint should issue. ${ }^{20}$ Those cases coming directly to the board's atten- . tion generally involve technical questions of law where it is essential to know if the board favors assuming jurisdiction as a matter of general administrative policy. At this stage of the case, the NLRB is interested neither in its substantive merit nor in the sufficiency of the evidence. The board's policy on this matter has been specifically defended by Board Member Edwin S. Smith in the following terms:

In its administrative role the Board, of course, does not desire a complaint to issue upon alleged facts which, even if proved, the Board does not think would constitute a violation of the Act. This administrative judgment, which is also a judicial judgment of the same sort which a judge exercises when he issues or refuses to issue a warrant on a preliminary set of facts which may later be tried before him, could not possibly affect the Board's later decision of the completed case. The Board, confronted with the many details which it handles every day would have the greatest difficulty at the time it comes to consider the record of a case, in recalling what the regional director had said about the case in a memorandum presented months before. After a complaint is issued the Board does not know, except in unusual instances, which of its lawyers will conduct the case, which trial examiner will sit upon the case or what is being presented during the hearing. The Board's mind is as unsullied from prior conceptions when it comes to pass final judgment upon a record as would be that of the most removed and aloof court. On the other hand, to have the body which in its judicial function is most fa-

I9 See Wolf, op. cit. supra note 5 , at 363 .

${ }^{20}$ See Smith, The Wagner Act and Labor Relations, NLRB Rel. R-I337, at 7 (November 1938). 
miliar with the interpretation of the Act impotent to decide in a doubtful situation that a case should not be allowed to go to hearing would cause much unnecessary inconvenience and disappointment to the parties at interest, to say nothing of a considerable waste of the taxpayers' money. ${ }^{2 x}$

Although the number of cases coming directly to the board's attention in this preliminary stage is perhaps greater than one might gather from Mr. Smith's statement, ${ }^{22}$ his conclusions are sound. It is obvious that the board must possess authoritative control over administrative policy. Where such control does not preclude the fair performance of the judicial function, there are no realistic grounds for genuine criticism.

Figures as to the percentage or actual number of cases in which a regional director's request for authorization to issue a complaint is refused either by the board or by the executive secretary are not available. One may safely conclude, however, that in the great majority of cases the opinion of the regional director is respected by the Washington office. In only rare instances has the NLRB directed issuance of a complaint where the regional director has previously refused a request. ${ }^{23}$ The latter's discretion is normally final, although central control is retained in all cases. This is necessary not only for the reasons indicated by $\mathrm{Mr}$. Smith, ${ }^{24}$ but also as an aid to the board's current policy of reducing to an absolute minimum the number of cases going to formal hearing. ${ }^{25}$

Before discussing problems in separation of functions in formal procedure, one further problem at the informal stage requires brief attention. Mediation activity by regional personnel bears directly on the question of separation of functions. The NLRB's regional offices have been criticized for engaging in mediatory activity, contrary to the express intent of the act. When the law was passed in I935, Congress deemed it unwise to

2I Ibid.

${ }^{22} \mathrm{It}$ is estimated that from ten to twenty percent of complaint and representation cases are taken directly to the board for its ruling as to whether a complaint should issue or whether an order should be given directing formal investigation and hearing in an " $R$ " case.

${ }^{23}$ Figures are not available on this point, but the percentage during the fiscal year ending June 30,1939 was between three and four percent.

${ }_{24}^{4}$ See note 20 supra.

${ }_{25}$ Regional directors have specific instructions to this effect. The criticism that the NLRB is unfair and biased in its treatment of the employer loses much of its force when it is recalled that the board is willing to proceed to a formal hearing on a complaint only when the preliminary investigation has revealed strong prima facie evidence of violation of the act and persistent refusal to comply. It should be noted that only a small minority of powerful employers, among them newspaper publishers, have continued to place themselves in a position not only of anti-unionism, but of deliberate defiance of the legislative, executive and judicial branches of the government. See Brooks, op. cit. supra note 18, at 80 . For newspaper anti-union activities see Seldes, Lords of the Press (1938). 
mix quasi-judicial and mediatory powers in the same agency. ${ }^{26}$ The essence of mediation is compromise. This was felt to be incompatible with the duties of interpretation and enforcement of a clear statutory mandate. Consequently, the board has issued instructions that no staff member may approve an informal settlement which accomplishes less than full compliance with the terms of the act. ${ }^{27}$ It is claimed that no deviation is permitted from this ruling.

Cases have been closed "by adjustment" (i.e. informally), however, where full compliance was not provided for in the settlement. For example, the employer and the union may reach an agreement independently of any action by an NLRB staff member, and the regional director may subsequently permit withdrawal of the charge. But in any case where the NLRB is officially a party to the conclusion of a settlement there must be strict adherence to the statute.

In administrative theory, the regional director is a participant in every case closed "by adjustment," but in actual fact he may not always be involved. It is impossible to estimate accurately the number of cases thus closed, which do not involve full compliance. Such reports are included with the board's informal files and are not open to general inspection. Undoubtedly, there is a certain amount of unofficial mediatory activity on the part of NLRB agents. But, if the union is satisfied with the terms of the settlement in cases of this type, there is nothing inherently reprehensible in the regional director's allowing the charge to be withdrawn, though he may be aware that the settlement is not in strictest conformity to the wording of the act. ${ }^{28}$

${ }^{26}$ The experience of the earlier labor boards under the National Recovery Administration had been an unhappy one, where the two functions were combined in the same agency. See Lorwin and Wubnig, Labor Relations Boards (1935).

${ }^{27}$ Wolf, op. cit. supra note 5 , at 368 .

${ }^{28} \mathrm{~A}$ different situation would present itself if there were evidence that the union was agreeing to the settlement unwillingly because of unfair practices or compulsion by the employer. Members of the state labor relations boards have inevitably been engaged in mediation activities to a greater extent than the NLRB. The Wisconsin board, under the original Wisconsin Labor Relations Act (see note 4 supra), has specific mediatory powers in addition to its quasijudicial functions, and New York and Pennsylvania have mediation laws as companion measures to their state labor relations acts. In Wisconsin, under the original measure, there was close co-operation between NLRB and state board officials in a number of cases. Representatives of the Wisconsin board accompanied NLRB investigators on complaint cases in the role of mediators. (Personal correspondence with J. K. Kyle, executive secretary of the old Wisconsin Labor Relations Board, August 8, x938). Through their mediatory powers, the state agencies often have an opportunity of settling disputes without formal proceedings and can often secure more flexible and rapid disposition of cases than would be possible under the quasi-judicial procedure of the NLRB. Unfortunately, however, state boards have been 
Several problems at the formal hearing raise serious questions as to separation of functions. All hearings in the field are presided over by trial examiners assigned from Washington by the chief trial examiner for the board. ${ }^{29}$ Formerly, board members occasionally sat as examiners, but the pressure of decision work has increased to the point where their direct participation is no longer practicable. Also, the board is now in a position to place greater reliance on its examiners than during the early years of the act's operation when great difficulty was experienced in securing and maintaining a competent examining staff.

The board has effected a complete functional separation between its trial examiners division and the litigation section of the legal division. The latter handles prosecutory work in the field and appears for the NLRB in court proceedings. The separation is also complete between trial examiners and the administrative staff of the regional offices. Dates for hearings are arranged by the regional director after consultation with the trial examiners division, but the former rarely knows which examiner will be assigned to a particular case, nor is there any contact between the examiner and the regional office prior to the hearing. ${ }^{30}$

The NLRB has issued instructions that there must be no relationship between the board attorney conducting the case and the trial examiner, other than that normally obtaining between judge and counsel. This is a deliberate step to avoid unintentional collusion between board examiners and attorneys. Where the two know each other personally, as is not infrequently the case, such a separation seems difficult to achieve. It is interesting to note that Professors Gellhorn and Linfield watched particularly for evidence of violation of the board's strict rule. They found none and their conclusions are worth quoting in detail:

While disregard of the Board's directions to its employees in this respect has never, so far as the authors are able to learn, been established by any respondents, several violations of its inflexible rule have been reported to the Board, and the participants in

handicapped by incompetent personnel and by hostile public opinion. New York's board is an exception to this generalization.

It has been suggested, with some plausibility, that the national law should be amended to give the NLRB mediatory powers. See Latham, Federal Regulation of Collective Bargaining, 6 Geo. Wash. L. Rev. I (I937). Such a change, however, goes to the substance of the statute and will not be considered further here. For an excellent discussion of the potential advantages in mediation by state boards see Garrison, Government and Labor: The Latest Phase, 37 Col. L. Rev. 897, 904 (I937).

29 The board now has a permanent staff of approximately forty trial examiners. Only on rare occasions are per diem examiners employed today.

${ }^{30}$ With rare exceptions, the trial examiner never makes an appearance in the regional office while hearing a case. 
the alleged conferences have been severely reprimanded by the Board even in the absence of substantiation of the reports. On the basis of rather careful inquiry, initiated with a considerable degree of skepticism, the authors have come to the conclusion that the relations between the Board's examiners and its attorneys are ordinarily not sharply different from those existing between many District Judges and United States attorneys; they are known to one another; they develop a certain respect for and confidence in one another; and attorneys learn something of the habits of mind of the judges; and are thus enabled to present their cases with some reference to their idiosyncratic individualities; they may even have social relationships; but they do not conspire together over the luncheon table to deny a fair trial to persons who are to be prosecuted by one and judged by the other. ${ }^{3 r}$

A further and less well-known example of the board's efforts to achieve a practical separation between judicial and administrative functions is found in its prohibition against trial examiners' having access to materials relating to the preliminary investigation of cases by the regional offices. Prior to the hearing, the examiner has no knowledge of the case, except what he can glean from the charge, the complaint and the answer. Occasionally, material on the preliminary investigation may be introduced into the record, ${ }^{32}$ but often considerable time elapses before the examiner gets the true gist of the situation.

While there may be ample theoretical justification for denying examiners access to such materials, in administrative practice such a policy has little in its favor. Judicial fairmindedness appears more likely to be assured by the examiner's having an accurate knowledge of the facts than by his remaining in virtual ignorance. The examiner is a judicial referee. But it is only fair to assume that the NLRB's trial examiners qualify as experts in the specialized field of labor relations and that, as a consequence, they will not be biased by reading preliminary investigation reports. As lawyers, they know well the difference between prima facie evidence and legal proof.

The trial examiners division has partially avoided the administrative difficulties inherent in this board policy. Examiners are now requesting counsel to make a preliminary statement for the record showing the facts of the case, what they intend to prove, and the testimony and evidence they plan to produce. Such statements give the examiner a clear picture at the outset. They help him to conduct the hearing with intelligence and fairness and to make informed rulings on subsequent motions and objections.

${ }^{31}$ Gellhorn and Linfield, op. cit. supra note 5, at 388.

${ }^{32}$ See In the Matter of Cleveland Equipment Works, 6 NLRB 773 (I938), where a field examiner's report was introduced into the record by stipulation of all parties at interest. 
The board's general policy on this matter, however, remains the same, although there is nothing requiring such a rule in either the statute or the board's rules and regulations. Actually, the law provides that if the board personally investigates a case, it is not thereby disqualified from participating in the decision of that case. ${ }^{33}$ In view of this provision, it is quite possible that Congress intended that it would be legitimate procedure for the trial examiner to have access to such materials.

Speaking realistically, concerted opposition from legal and employer groups would develop if the board were to change its ruling on this question. All parties would demand that the board's informal files be made generally accessible. ${ }^{34}$ With such potential hostility in mind, the NLRB will doubtless adhere to its present policy, at least until such time as greater confidence in the ability and judicial temper of its examining staff develops. A change in policy now would mean still further delaying of formal proceedings by employers' counsel, who might question in each instance whether the examiner's report was in fact based on considerations found in the record. Or it might be alleged that the examiner had prejudged the issues. Elimination of the present ruling might also impair the NLRB's relatively satisfactory standing with the federal courts. As a consequence, it is not seriously urged that the board rescind its policy. The extensive discussion was intended to demonstrate the possible impairment of the judicial function resulting from a rule designed to conform rigidly to the prevailing dogma that judicial and administrative functions should not be mixed.

Probably no other specific phase of the NLRB's formal procedure has aroused more comment from outside groups than the conduct of formal hearings. Statements on NLRB hearings range the gamut from extreme favor to extreme disfavor. On the one hand, there is the opinion of the CIO general counsel that the NLRB gives "the fairest hearing of any similar tribunal in the federal government." 35 Also on the favorable side of the ledger is the fact that the board has received well over two hundred unsolicited letters from employer counsel praising the conduct of hearings.

33 Section 5 of the act reads in part, "A member who participates in such an inquiry shall not be disqualified from subsequently participating in a decision of the Board in the same case."

34 The AFL at the last session of Congress submitted a cautiously worded but dangerous amendment along these lines. It suggested that "Subject to reasonable rules and regulations of the Board, parties to a proceeding may examine the files in such proceeding." Such an amendment should be rejected. The writer feels that any administrative tribunal with prosecutory functions should have the privilege of keeping private files.

35 Interview with Lee Pressman, November 1938. 
But by other sources NLRB hearings have been characterized as a species of "inquisition," ${ }^{6} 6$ trial examiners have been burned in effigy, ${ }^{37}$ and criticized constantly for bias prejudicial to the interests of the parties involved..$^{8}$

Certain procedural features at the hearing stage directly involve the problem of separation of functions. Of prime importance is the proper function of the trial examiner and the attorney for the board. The NLRB has a clear duty under the act to obtain a complete and truthful factual record in both complaint and representation cases. For this reason, trial examiners know that they are personally responsible for any gaps in the record. This is of fundamental importance, since almost every case heard before an examiner results in a board decision; 39 and the justness of the latter depends on the fidelity with which the former carries out his prescribed duty. While the examiner is essentially a judicial officer, he has this additional obligation of developing a complete record for the benefit of the board. If necessary, he may and does participate in questioning of witnesses, he may advise counsel as to lines of testimony they should develop, or he may himself introduce evidence. ${ }^{40}$ The examiner cannot take refuge in the fact that the board's attorney or employer's counsel have been negligent in their own duties.

When a trial examiner questions witnesses, criticism has arisen that in so doing he is abandoning his proper judicial role. The writer emphatically disagrees with such a viewpoint. Again it must be stressed that examiners are presumed to be administrative experts as well as lawyers. The fact that they may participate in questioning witnesses, or even in the introduction of evidence, does not ipso facto destroy their judicial temperament and thus derogate from their primary function. Board hearings are

${ }^{{ }^{6}}$ See Bridges, op. cit. supra note 6 . This article by a United States Senator is typical of the condemnations of the NLRB in the daily press. Employers have become so accustomed to reading material of this sort that they are surprised when they learn it is far from the truth. At one board hearing, the employer's attorney arose and opened his remarks with the following statement, "I fully expect to have every objection I make overruled during the course of this proceeding." As Board Member Edwin Smith points out, "Obviously, it is very difficult for agents of the Board to conduct hearings in an equitable and reassuring manner when the employer expects that he is invited to appear at a species of public lynching." Smith, op. cit. supra note 6.

${ }^{37}$ This occurred during the hearing on the Weirton Steel Company complaint case.

${ }^{38}$ This is invariably alleged in exceptions to the examiners' intermediate reports, although such allegations rarely have had foundation in fact.

39 Except a small minority which may be dropped by either party for a miscellany of reasons. Any stipulation to a consent order or to an agreed settlement concluded after or during a formal hearing is embraced in a formal board decision and order.

${ }^{\circ} \mathrm{This}$ is permitted both by the act and the board's rules and regulations. 
not the arena for a game where the examiner can watch calmly to see which side will win, or which attorney can outsmart his opponent. The policy of the board is to secure the whole truth. If the examiner becomes too "judicial," the purpose of the whole proceeding may well be defeated by his inactivity.

Participation by examiners appears to vary with the individual. Some will assume a passive role, contenting themselves with a bare minimum of rulings on motions and objections; others actively interrogate witnesses and counsel and often appear to fill out a greater share of the record than all attorneys combined. Participation by the examiner is more frequent in representation case hearings since, somewhat surprisingly, it is more difficult to achieve a complete record here than in the average complaint case. ${ }^{4 \mathrm{I}}$ Another factor is the restraint imposed on an examiner in a complaint proceeding because of the dual function of the board in such cases.

Active participation on the part of examiners is a delicate problem and essentially one of degree. It has drawn the attention of circuit courts in recent cases, ${ }^{42}$ notably the Montgomery $W$ ard case ${ }^{43}$ where a new hearing was ordered by the court. It held that the examiner's conduct in that instance had "shaded into partisan activity" and that the respondent had therefore been denied a fair hearing as guaranteed by due process of law. In a more recent case, the trial examiner was censured by the court for exaggerated participation, although his conduct was not held to have been prejudicial to the interests of the respondent. The opinion concludes with a sentence indicating the view that federal courts may be expected to adopt toward participation by examiners. The court said:

If a trial examiner will only keep in mind that the proper exercise of his functions requires openmindedness, fairness and impartiality, and if he will, within reasonable limits, permit each of the parties to the proceeding before him to prove his own case, in his own way, by his own counsel, he will save himself from criticism and avoid furnishing any basis for a charge that the hearing was unfair and that bias was shown. ${ }^{44}$

NLRB examiners have frequently been criticized for an anti-employer bias. The writer has found no evidence of such bias in records which he

${ }_{41}$ This is true principally for two reasons. In the first place, complaint cases involve legal questions, whereas representation disputes involve factual and political problems with room for a wide divergence of opinion. Secondly, the questions in representation cases, such as what is the appropriate unit for purposes of collective bargaining, are relatively novel and often complex.

${ }^{42}$ See Cupples Co. v. NLRB, I06 F. (2d) 100 (C.C.A. 8th 1939).

${ }_{43}$ Montgomery Ward \& Co. v. NLRB, I03 F. (2d) 147 (C.C.A. 8th I939); see also Inland Steel Co. v. NLRB, C.C.H. Lab. Law Serv. Ir85 to (C.C.A. 7th I940).

44 Cupples Co. v. NLR.B, I06 F. (2d) I00 (C.C.A. 8th r939). 
examined. ${ }^{45}$ While such criticisms may have foundation in isolated cases, it is felt that in most instances they are based upon a fundamental misconception of the NLRB's general approach in the field of labor relations. "The Board, through its trial examiners, seems .... to regard the cases from the viewpoint of a management engineer, familiar with Management's prejudices and traditional attitude towards Unions, but charged especially with the duty of protecting the rights of the employees." ${ }_{46}$ Assuming this statement to be a correct interpretation of board policy, the greater latitude admittedly accorded to employee testimony in complaint cases is more readily understood. As the chairman of the board has remarked, while employers may sometimes fool the board, they never fool the employees. ${ }^{47}$

Where the NLRB has found evidence of bias on the part of its examiners they have been dismissed. ${ }^{8}$ A number of cases have been sent back for rehearing on the board's own motion before another examiner because of prejudicial error on the part of the original examiner ${ }^{49}$ or because of proven bias. ${ }^{50}$ Objections by any party to the conduct of the hearing by the examiner automatically become part of the record, reviewable by the board and the courts.

While an NLRB hearing is in progress, efforts are often continued to achieve an informal settlement, in order to avoid a costly and protracted proceeding. Such efforts are generally made by the regional director, but

${ }_{45}$ In all, the writer examined the complete formal file in twenty-five cases selected as representative.

${ }^{4}$ Feller and Hurwitz, How to Deal with Organized Labor 594 (I937). It might be noted that this book, while written primarily for employer consumption, concludes as to board hearings and its procedure generally in complaint cases, "It is not intended here to charge the NLRB with undue severity towards employers." Ibid., at 595.

47 Tbid., at 594 .

${ }^{48} \mathrm{~A}$ noteworthy case is that of $\mathrm{J}$. Raymond Walsh, former instructor in economics at Harvard University. Dr. Walsh had been employed as a per diem examiner by the NLRB, but the board declined to use him further when it was found that his book, CrO: Industrial Unionism in Action (I937), showed a marked preference for the CIO as opposed to the AFL. This action of the board was protested in a letter to Chairman Madden by the AFL attorney who had argued before Walsh in the latter's final case. He urged Walsh's retention and asserted that his conduct of the hearing had been above reproach. See also In the Matter of Express Publishing Co., 8 NLRB I62 (1938), in which the board ordered a new hearing before a different examiner because of possible bias against the employer on the part of the original examiner due to an anti-NLRB editorial in the respondent's paper.

49 Definite figures on this are not as yet available. For examples, see In the Matter of H. Margolin \& Co., 9 NLRB 852 (I938) and In the Matter of Holland Reiger Division of Apex Electric Co., 6 NLRB 156 (1938).

so See Montgomery Ward \& Co. v. NLRB, ro3 F. (2d) I47 (C.C.A. 8th I939); Inland Steel Co. v. NLRB, C.C.H. Lab. Law Serv. II8I50 (C.C.A. $7^{\text {th }}$ I940). 
not infrequently the examiner may be asked to participate in settlement conferences. Here again is a ticklish problem in separation of judicial and administrative functions which has attracted no attention in earlier legal comment on the work of the NLRB.

NLRB trial examiners have participated in settling informally both complaint and representation cases. There is no board rule prohibiting their participation. They have discretion in the matter with the implied understanding that they should conduct themselves in such a manner as not to be subject to disqualification from further formal proceedings in case the settlement is not consummated. For example, if the weight of the evidence should be discussed informally before the examiner, he is automatically barred from further participation in the case. The board is most strict on this point. A trial examiner must be careful not to exhibit bias, prejudice or to make statements of his own personal feelings as to the proper disposition of the case. If he participates at all, his sole duty is to make every effort to bring the parties into accord. If he enters a settlement conference which subsequently falls short of fruition, he is generally not continued on the case. A new examiner is assigned who reads the entire previous record and presides at the reopening of the formal hearing.

Informal settlements concluded during the hearing clear officially through the regional director, since the examiner has no formal powers in such proceedings. Some examiners are reluctant to participate even to a limited degree in settlement conferences. Others engage in them freely, in some cases to the point of actually drafting the terms of the settlement. It should be emphasized that examiners never participate in a settlement conference except upon request of the parties at interest. The individual complexion of the case and the temperament of the examiner generally determine whether a request to participate will be complied with or refused.

Trial examiners can perform a valued service in many cases where the parties are near agreement, but where personal animosity may prevent their concluding the matter successfully among themselves. The objection to participation by the examiner is based primarily on the theory that in so doing he is forsaking his purely judicial role. This criticism is not fundamental. It ignores completely the well-known fact that many courts of law follow a similar practice constantly. Divorce court proceedings may be cited as a familiar illustration.

The proper function of the attorney for the board must now be considered before leaving the hearing stage. Employer ire has often been aroused by the occasional close collaboration between the board attorney 
and counsel for the union filing the charge in a complaint proceeding. When the NLRB, in its prosecutory capacity, has undertaken to press such a charge in a formal hearing, it is difficult to understand what is prejudicial to any party in the assistance rendered to the board's attorney by the legal representative of the allegedly aggrieved union. The relations of the board's attorney and union counsel in a complaint case do not appear to be essentially dissimilar in any respect to the normal relationship existing between counsel and client in ordinary court proceedings.

In his prosecutory function, the board's attorney is directly responsible to the associate general counsel in charge of the litigation section of the legal division. But it should be noted that neither the attorney at the hearing nor his associate general counsel is in direct consultation with members of the board in connection with particular cases, except where there may be an extraordinary development affecting the general administrative policy of the NLRB. "Even in the exceptional case, however, the members of the board take no further direct interest in the case after the question of policy has been decided." $5 x$

Employers have occasionally protested against the use of NLRB staff members as witnesses in complaint case prosecutions. This is cited as further proof that the cards are stacked against the employer. In actual practice, such testimony is generally confined to members of the division of economic research and is usually offered by the NLRB's chief economist. Admittedly, testimony by NLRB field examiners or regional directors in cases where they had made the preliminary informal investigation would be distinctly undesirable. If this were permitted, it would be virtually impossible for regional personnel to retain whatever confidence employers might have been willing to place in them in the informal stages of subsequent investigations. The employer would become suspicious or antagonized and the chances of achieving informal compliance with the act would be greatly reduced. No prejudicial danger to the interests of any party can be discerned, however, in calling members of the board's economic division as background witnesses in cases where they have normally had no prior contact with the proceedings.

To sum up the discussion of problems at the formal hearing stage, the writer feels that criticisms of the board's policies and procedure have been of minor significance or have been purposely advanced with the intention of discrediting the Wagner Act and the board itself. While in isolated instances it may be true that the employer has not had a completely fair hearing, this is doubtless due to failure of personnel in the individual case, ${ }_{5 x}$ NLRB Third Ann. Rep., at 5 ( 1938 ). 
rather than to any inherent defect in NLRB procedure. A sense of fairness is a human rather than a mechanical concept. Personnel in administrative tribunals cannot be expected to attain infallibility any more than any other governmental ${ }^{52}$ or private agency. With further refinement and perfection in the board's legal and trial examining staff, genuine criticism may be expected to diminish. ${ }^{53}$

Several problems relating to separation of functions arise at the decision phase. In most complaint cases, the examiner submits an intermediate report to the board containing an analysis of the record together with his recommendations as to disposition of the case. Such a report is not essential to due process, ${ }^{54}$ but is furnished the respondent in virtually every case. In those cases where the report is not called for, the board always issues "proposed findings of fact and proposed conclusions of law" and permits oral argument following its proposed order. 55 This is an illustration of a procedural safeguard afforded by NLRB policy which is unnecessary so far as the constitutional concept of a fair hearing is concerned. When the intermediate report has been approved as to form and conclusions of law by the chief trial examiner, any formal connection of the trial examiners division with the case is at an end. The entire record is then turned over to the review section in the legal division, a functionally separate unit.

It would be naive to presume that any administrative tribunal actually examines the entire record in every case prior to rendering its decision. The NLRB is no exception. At the present time, it has been estimated

${ }_{52}$ It might not be out of place to remark that judges themselves have by no means been immune from criticisms on the grounds of bias and prejudice.

53 Of course many private attorneys, unaccustomed to certain novel variations in administrative procedure, will doubtless continue to protest that they are denied their "day in court," since the rules of evidence employed in ordinary judicial proceedings are not strictly adhered to by the NLRB. As a matter of administrative practice, NLRB attorneys have found it expedient in most cases to follow court rules of evidence in order to avoid interminable bickerings and delays on the part of employer counsel.

54 See particularly NLRB v. Mackay Radio \& Telegraph Co., 304 U.S. 333 (I938).

ss There is no conflict between NLRB procedure in complaint cases and the standards laid down by the Supreme Court in the second Morgan case, $3^{\circ} 4$ U.S. I (1938). The latter decision covered a case where the deciding administrative officer did not himself make the findings. The Court held that the procedure in such cases was vitally defective where the respondents were denied a reasonable opportunity of knowing the claims presented by the active prosecutors and to contest them. In NLRB complaint procedure, adequate notice of the nature of the charge is given to the employer even before jurisdiction is taken and opportunity to attack the allegations of the board as complainant is afforded at several stages during the proceedings. See particularly Sears, The Morgan Case and Administrative Procedure, 7 Geo. Wash. L. Rev. 726 (1939); Judicial Control of Administrative Procedure: The Morgan Case, 25 Harv. L. Rev. $5 \circ 9$ (1939). 
that the board on its decision days disposes of as many as nine cases per day..$^{56}$ The tremendous volume of decision work since the Supreme Court upheld the Wagner Act in the spring of $1937^{57}$ has required an increasingly large staff of legal assistants to the board. That such assistance violates no constitutional principle is well settled. The courts have stated on several occasions that administrative tribunals may be aided in the analysis and digesting of records and in the drafting of decisions. ${ }^{58}$ To quote from a recent circuit court opinion involving an NLRB order, "We feel that the inquiry into the mechanics of opinion-writing is ethical rather than legal. ... . We may add that the Labor Board has never made any mystery of the part taken by the attorneys in its 'Review Division' in aiding it in writing its opinions." 59

At the review phase there is a definite problem in separating judicial from prosecutory functions. For this reason, by explicit board regulation, review section attorneys may not discuss any case on which they are working with the regional attorney who prosecuted the case at the hearing. The latter occasionally appears at oral argument and may, in rare instances, argue the case before the board, but he has no contact with the Washington attorney reviewing the case. ${ }^{60}$

The general counsel of the board exercises general supervision over both sections of the legal division. In cases where he has played no active part, he may be consulted by members of the review section, particularly on jurisdictional matters. But if, as may occasionally be true, he has participated in a case in its investigatory or prosecutory phases, there is no contact between him and the review attorneys. There is a certain amount of interchange in personnel between the litigation and review staffs, but attorneys transferred from prosecutory duties to the review section are naturally never assigned to cases with which they have been previously connected in the field.

Less strict separation is maintained between review attorneys and trial examiners. Since both are performing quasi-judicial functions, any argu-

${ }^{56}$ This estimate includes both complaint and representation cases.

${ }^{57}$ NLRB v. Jones \& Laughlin Steel Co., 30 r U.S. I (r937), is the leading case of five test suits.

$5^{8}$ See the first Morgan case, 298 U.S. $468,48 \mathrm{I}-2$ (1936), where the Court said, "Evidence may be taken by an examiner. Evidence thus taken may be sifted and analyzed by competent subordinates." Cf. NLRB v. Biles Coleman Lumber Co., 98 F. (2d) I6 (C.C.A. 9th I938), citing the Morgan case as authority in reference to the NLRB's procedure.

s9 NLRB v. Botany Worsted Mills, 106 F. (2d) 263 (C.C.A. 3 d 1939).

60 The writer attended oral arguments before the board in some twenty " $C$ " cases. In only one of these was the prosecuting attorney for the board present. He took no part, nor was there any interchange between him and the review section attorney. 
ment for their complete separation carries no weight. The fact that it is occasionally necessary for the review attorney to consult the examiner may be indicative of defective handling of the case at the hearing. The record may not be complete or intelligible on certain crucial points, and in such instances the examiner may be asked to clear up the difficulty. It is necessary in some cases to send the matter back for rehearing where gaps in the record are revealed by the review attorney's analysis.

To sum up, the writer feels that the NLRB has succeeded with remarkable and commendable effectiveness in achieving a clean-cut and at the same time administratively practicable separation of conflicting functions within its organization. Assuming such a separation to be a sine qua non of administrative fairness, the NLRB unquestionably measures up. Criticism of the board's policies must use another base if it is to find its mark.

The NLRB has enforced its policy of separation from the beginning. In common with other federal administrative tribunals, it has found it expedient, if not necessarily desirable, to divide its administrative, prosecutory and judicial activities as far as possible. Administrative investigation is made by regional office personnel. Prosecution is in the hands of the litigation section of the legal division, but all formal hearings are presided over by trial examiners, who are organizationally, functionally and personally separate from the prosecutory staff. Analysis of the record for purposes of a decision is made by a review attorney who has had no prior connection with the case. The decisions are those of the board itself in every case, although they may be physically written by legal assistants. The board members have no previous knowledge of any case, except in a minority of instances where a ruling was essential covering general administrative policy. The inevitable personal contacts between members of the various divisions of the NLRB are not calculated in any way to impair the proper performance of the judicial function.

If the above discussion of the NLRB and separation of functions is an accurate and fair statement of board policy and practice, the writer can see no legitimate reason for transferring the judicial functions of the board either to another administrative body ${ }^{6 x}$ or to the federal courts. ${ }^{62}$ At best,

6x The President's Committee on Administrative Management suggested this as a general plan for administrative tribunals, without making definite recommendations as to individual agencies. For criticism of such a proposal see Landis, The Administrative Process (ro38).

${ }_{2}$ Those interested in destroying the Wagner Act and the NLRB without assuming the actual onus for repealing the law have suggested transferring the board's judicial functions to the federal district courts. Aside from the fact that the latter are unfamiliar with the specialized subject matter of labor relations, to give them initial and review powers would cause in- 
any such change would mean still further delay in those cases requiring formal procedure and would not increase the protection now afforded to parties at interest. At the worst, it would mean destruction of any honest effort at administering the act.

The present procedure of the NLRB in both " $C$ " and " $R$ " cases provides adequate safeguards to both employers and unions. It is worth repeating that the policies of the board in not a few instances are more liberal than necessary to satisfy "the rudimentary requirements of fair play" as laid down by the federal courts. The automatic granting of oral argument upon request in complaint cases is one excellent illustration. Another, already mentioned, is the serving of an intermediate report or a proposed order to which the parties may except either verbally or in writing, or both.

The latest judicial pronouncement in the second Morgan case $^{63}$ asserts that a fair and open hearing before an administrative tribunal must contain certain essential elements. Said the Court, ${ }^{64}$

The right to a hearing embraces not only the right to present evidence, but also a reasonable opportunity to know the claims of the opposing party and to meet them. .... Those who are brought into contest with the Government in a quasi-judicial proceeding aimed at the control of their activities are entitled to be fairly advised of what the Government proposes and to be heard upon its proposals before it issues its final command.

NLRB procedure meets and surpasses these judicial standards. Further, any party considering himself to be aggrieved wholly or in part by a board order is entitled to judicial review before any positive action against him can be taken. Where such ample safeguards exist and where the administrative body in question continues strictly to enforce a deliberate and self-imposed policy of separating its administrative, prosecutory and judicial functions, there is not the remotest danger of "administrative absolutism." ${ }_{55}$ It might be fitting to close with a pregnant epigram from a recent circuit court decision sustaining an order of the NLRB. Remarked the court, "Administrative Justice is consistent, not incompatible, with our Supremacy of the Law."66

tolerable delays and thus destroy the efficacy of the board. Labor relations is a field peculiarly dependent upon a speedy and effective resolution of disputes and hence is particularly suited to the administrative medium.

${ }^{63} 304$ U.S. I (1938). $\quad{ }^{64} 304$ U.S. I, I8 (I938).

65 The favorite phrase of the American Bar Association's Committee on Administrative Law in their 1939 Report to the Association.

${ }^{66}$ Jefferson Electric Co. v. NLRB, IO2 F. (2d) 949 (C.C.A. $7^{\text {th }}$ I939). The italics in the above quotation are those of the court. 